\title{
Syphilitic retinitis and panuveitis simulating acute retinal necrosis: case report
}

\author{
Retinite e panuveíte por sífilis simulando necrose aguda de retina: \\ relato de caso
}

Felipi Zambon ${ }^{1}$

Frederico Lírio Nascimento Silva ${ }^{2}$ Adhele Furlani de Sá Cavalcante ${ }^{3}$ Yoshitaka Nakashima ${ }^{4}$ John Helal Jr. ${ }^{5}$
Work carried out at the Department of Ophthalmology and Otorhinolaringology, Hospital of Clinics, Faculdade de Medicina da Universidade de São Paulo - USP São Paulo (SP) - Brazil.

Preceptor, Ophthalmology Department, Hospital of Clinics, São Paulo University - USP - São Paulo (SP) Brazil.

${ }^{2}$ Resident, Ophthalmology Department, Hospital of Clinics - USP - São Paulo (SP) - Brazil.

${ }^{3}$ Fellow, Ophthalmology Department, Hospital of Clinics - USP - São Paulo (SP) - Brazil.

${ }^{4} \mathrm{MD}$, Associate Professor, Ophthalmology Department, Hospital of Clinics - USP - São Paulo (SP) - Brazil.

${ }^{5} \mathrm{MD}$, Associate Professor, Ophthalmology Department, Hospital of Clinics - USP - São Paulo (SP) - Brazil.

Correspondence address: FelipiZambon. Av. Dr.Enéas Carvalho de Aguiar, 255 - São Paulo (SP)

CEP 05403-000

E-mail: felipizambon@ @otmail.com

Recebido para publicação em 19.07.2009

Última versão recebida em 28.10.2009

Aprovação em 09.11.2009

Nota Editorial: Depois de concluída a análise do artigo sob sigilo editorial e com a anuência do Dr. Luiz Carlos Molinari Gomes sobre a divulgação de seu nome como revisor, agradecemos sua participação neste processo.

\begin{tabular}{|l|}
\hline ABSTRACT \\
\hline Retinitis and panuveitis in immunocompetent patients is a rare and sight- \\
threatening disease, of difficult diagnosis. A case of a 31-year-old male \\
who presented with unilateral placoid retinitis and panuveitis, \\
unsuccessfully treated as acute retinal necrosis, that in fact was syphilis, \\
with neurosyphilis and excellent response to treatment is reported. \\
\hline
\end{tabular}

Keywords: Eye infections; Syphilis; Neurosyphilis; Uveitis; Retinitis; Sexually transmitted diseases; Human; Male; Adult; Case reports

\section{INTRODUCTION}

Retinitis and panuveitis is a rare and sight-threatening condition, being in most cases a diagnostic and therapeutic challenge. Empiric treatment is often initiated, due to the severity of the disease, based only on clinical findings. Immunocompromised patients with the disease are usually affected by ocular infectious diseases or ocular lymphoma, while the immunocompetent ones show autoimmune and connective tissue disorders in addition to the previous causes ${ }^{(1)}$.

The panuveitic cases related to infectious diseases are perhaps the most dramatic ones, especially when associated with neuritis or retinitis, causing profound and rapidly progressive visual loss, with increased incidence of contralateral affection without correct treatment ${ }^{(2)}$. Among the possible agents are the herpes viruses, syphilis, Lyme disease, tuberculosis, endogenous endophthalmitis and fungi $i^{(1)}$. Syphilis is a re-emerging disease, with a constellation of ocular manifestations, requiring high level of suspicion for diagnosis ${ }^{(3)}$.

A case of a young immunocompetent patient with unilateral panuveitis and associated retinitis caused by syphilis is reported, highlighting the diagnostic challenge and the evolution with specific treatment.

\section{CASE REPORT}

A 31-year-old black male, from São Paulo, Brazil, presented at the emergency of the Hospital of Clinics, complaining of redness, pain and vision loss in his right eye, accompanied by holocranial headache in the last 15 days. His past medical and ocular history were unremarkable, except for an ulcerated genital lesion diagnosed and treated in an external service two months earlier. He was heterosexual and referred several unprotected sexual relations in the last years. 
The initial examination revealed best corrected visual acuity of hand motions in right eye and 20/20 in the left. Biomicroscopy of the right eye showed anterior uveitis with keratic precipitates and $1 \mathrm{~mm}$ hypopium, and fundoscopy showed severe vitreitis and extensive white-yellowish retinal lesions, affecting the macula, the juxta-papillary region and the superior nasal and inferior temporal periphery (Figure 1). Intraocular pressure was $9 \mathrm{mmHg}$ and $12 \mathrm{mmHg}$, and the exam of left eye was normal.

Serologic testing for toxoplasmosis, toxocariasis, syphilis, cytomegalovirus, varicella-zoster virus, herpes simplex viruses 1 and 2 and HIV were collected. Tuberculin skin test, chest X-ray and hemogram were also performed (Table 1). In the emergency, only hemogram, chest X-ray and HIV testing results were available and revealed no abnormalities.

A diagnosis of acute retinal necrosis was suspected and the patient was admitted and treated with intravenous acyclovir $4000 \mathrm{mg}$ per day divided in five doses, and ocular topical $1 \%$ prednisolone acetate and tropicamide. In the first two days, there was a slight improvement in anterior uveitis, but fundoscopic findings were maintained. Ultrasound examination revealed choroidal thickening and attached retina.

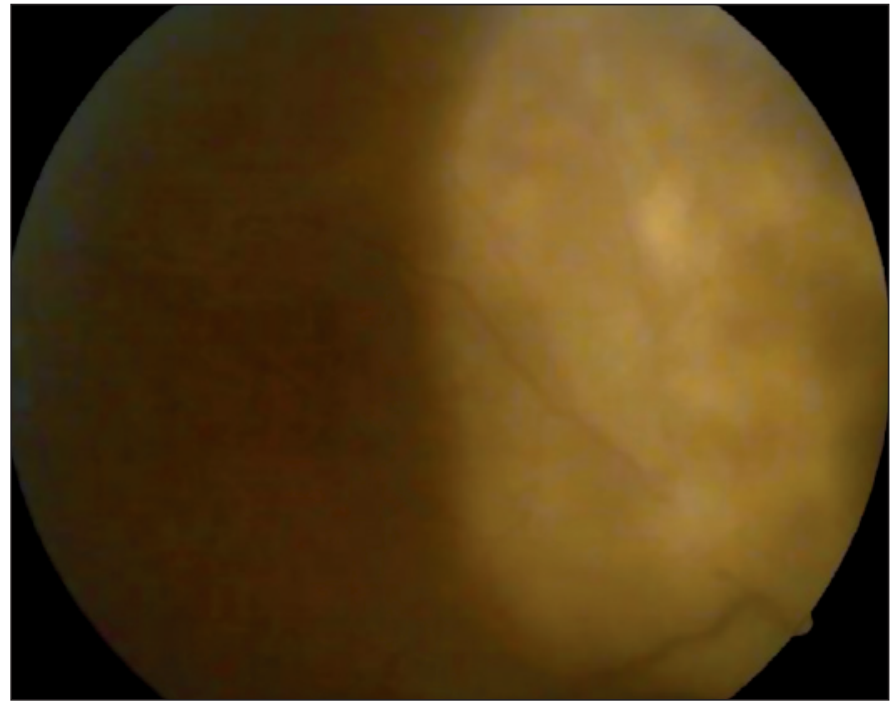

Figure 1 - Fundoscopic aspect - superior temporal region

Table 1. Serologic and complementary tests

\begin{tabular}{lll|} 
Serologic/complementary test & \multicolumn{2}{c|}{ Result } \\
Toxoplasmosis & Negative & \\
Toxocariasis & Negative & \\
HSV-1 and 2 & IgM negative & IgG positive \\
Varicella-zoster virus & IgM negative & IgG positive \\
Citomegalovirus & IgM negative & IgG positive \\
Hemogram & Normal & \\
Tuberculin skin test & Weak reactor & \\
VDRL & Reagent $1 / 4$ & \\
\hline
\end{tabular}

In the third day, $40 \mathrm{mg}$ oral prednisone was added to the treatment scheme. After 14 days the patient was discharged with oral acyclovir, without visual improvement. Serologic results were all negative, except for VDRL testing, that was reagent with 1:4 dilution. Treponemic testing for syphilis was in analysis. Four days later, the patient returned, without anterior ocular inflammation, but with vision of no light perception, and worsening of the fundoscopic lesions, now with new focal areas of exudation (Figure 2). Treponemic serological testing confirmed syphilitic infection, and a liquor sample was collected, revealing lymphomonocitic pleocytosis, with positive hemagglutination test for syphilis (Table 2).

The patient was readmitted and treated with intravenous crystalline penicillin, 18 million units per day, with rapid improvement of fundoscopic aspect of the right eye and negativation of liquor VDRL after 14 days, but maintained vision loss.

\section{DISCUSSION}

Syphilis had a decreasing prevalence along the years, but it is experiencing a new rise in the number of cases in the last

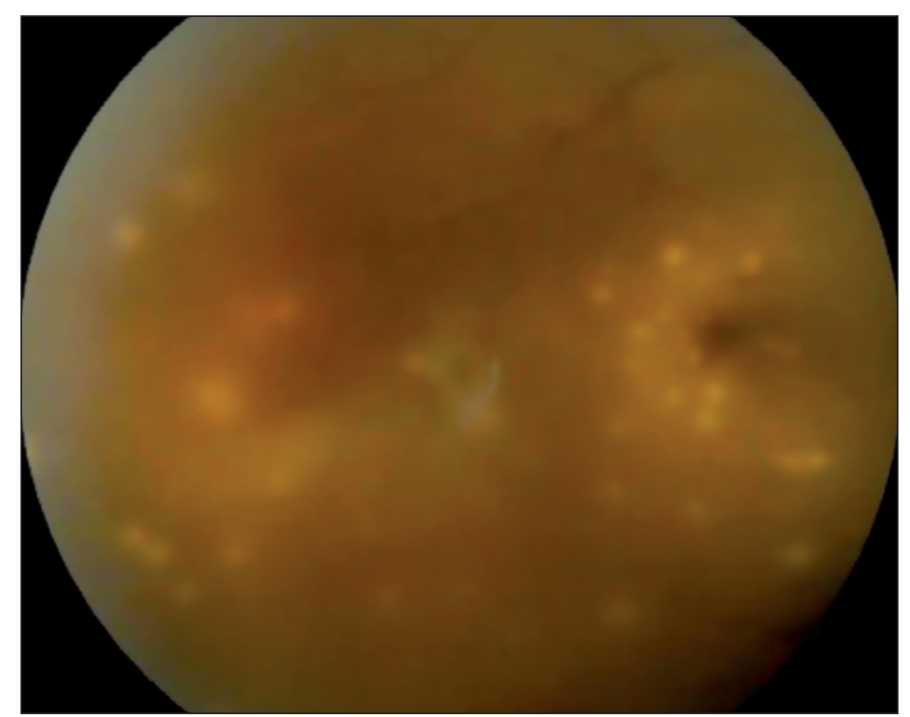

Figure 2 - Macular aspect after treatment with acyclovir and corticosteroid

Table 2. Liquor analysis before penicillin treatment

\begin{tabular}{lc|} 
Liquor parameter & Result \\
Cell count & 545 cells $/ \mathrm{mm}^{3}$ \\
Lymphocytes & $90 \%$ \\
Monocytes & $7 \%$ \\
Plasmocytes & $2 \%$ \\
Neutrophils & $1 \%$ \\
Protein & $33 \mathrm{mg} / \mathrm{dL}$ \\
Glycosis & $58 \mathrm{mg} / \mathrm{dL}$ \\
VDRL & Reagent $1 / 1$ \\
Hemagglutination for syphilis & Positive $1 / 128$ \\
\hline
\end{tabular}


decade in several countries around the world, including Brazil, United Kingdom and United States of America, that experienced a $33,5 \%$ increase in the incidence between 2000 and $2004^{(3)}$. Ocular disease by syphilis is rare, affecting about $2.5 \%$ to $5 \%$ of patients with tertiary disease. The ocular manifestations may be diverse, with previous descriptions of focal retinitis, papillitis, iritis, keratic precipitates, periphlebitis, vitreitis and serous retinal detachment ${ }^{(4-5)}$, making the diagnosis based solely in clinical findings impossible ${ }^{(6)}$, and thus requiring high level of suspicion for its detection.

A case of ocular syphilis, with multifocal retinitis and placoid lesions, associated to intense intraocular inflammation, initially diagnosed as a viral retinitis and treated as acute retinal necrosis (ARN) is reported. ARN is a serious condition, in most cases caused by viral infection with increased risk of bilaterality without proper treatment ${ }^{(2)}$. The patient met the diagnostic criteria proposed by the America Uveitis Society for $\mathrm{ARN}^{(7)}$ and was initially treated with antiviral therapy, with association of systemic corticosteroid in the following days. Misdiagnosed cases like this were reported, and many diseases may simulate ARN, including toxoplasmosis, fungal endophthalmitis, Behçet disease and ocular lymphoma ${ }^{(8)}$. However, even with the possible diagnosis of syphilis or other diseases in mind, due to the severity of necrotizing viral retinitis, for some the initial treatment remains the use of antiviral therapy until the definitive diagnosis $^{(1)}$, that may require vitreous or aqueous humor aspirates with antibody dosage, polymerase chain reaction, cytology and cultures for specific agent ${ }^{(9)}$.

The acute syphilitic posterior placoid choriorretinitis was first described in $1990^{(9)}$, and the clinical picture was initially thought to be due some kind of immunosupression, like HIV infection or corticosteroid usage. Recent reports, however, showed that this clinical presentation may also affect immunocompetent patients as one of the various presentations of ocular syphilis instead of an atypical form related to immunedepression $^{(10)}$. The reported patient had no known previous immune diseases, and presented with placoid retinitis, with increase of its severity after the use of systemic corticosteroids, demonstrated by the appearing of new whitish retinal lesions with time.

Ocular syphilis, initially described as part of tertiary disease, may occur in any phase of the systemic infection. Many cases with ocular disease have concomitant central nervous system (CNS) involvement, and investigation of neurosyphilis with liquor puncture is recommended for some authors. Even with no clinical evidence of CNS disease, the treatment of the ocular disease should be that of neurosyphilis, with 1824 million units of intravenous crystalline penicillin per day, for 10-14 days, because some patients treated with intramuscular regimen of penicillin have developed ocular manifestations ${ }^{(5)}$.

It is important to know that even with proper treatment, the recurrence of the disease is possible, and the patient must be followed for a long period.

Syphilis is a re-emerging disease in the world, and because of its various presentations, it is necessary to keep it in mind as a differential diagnosis in clinical practice for correct diagnosis and treatment.

\section{RESUMO}

Retinite com panuveíte em pacientes imunocompetentes é um condição rara e ameaçadora para a visão, e de difícil diagnóstico. É relatado um caso de um paciente do sexo masculino com 31 anos de idade, que se apresentou com retinite em placas e panuveíte, inicialmente tratado sem sucesso como necrose aguda de retina, que na verdade era um caso de sífilis ocular, com afecção do sistema nervoso central e ótima resposta ao tratamento sistêmico para sífilis.

Descritores: Infecções oculares; Sífilis; Neurossífilis; Uveíte; Retinite; Doenças sexualmente transmissíveis; Humano; Masculino; Adulto; Relatos de casos

\section{REFERENCES}

1. Huang C, Park S, Castellarin AA, Pieramici DJ, Cunningham ET Jr. Diagnostic and therapeutic challenges. Retina. 2007;27(3):385-90.

2. Palay DA, Sternberg P Jr, Davis J, Lewis H, Holland GN, Mieler WF, et al. Decrease in the risk of bilateral acute retinal necrosis by acyclovir therapy. Am J Ophthalmol. 1991;112(3):250-5.

3. Chao JR, Khurana RN, Fawzi AA, Reddy HS, Rao NA. Syphilis: Reemergence of an old adversary. Ophthalmology. 2006;113(11):2074-9.

4. Jumper JM, Machemer R, Gallemore RP, Jaffe GJ. Exudative retinal detachment and retinitis associated with acquired syphilitic uveitis. Retina. 2000; 20(2):190-4.

5. Browning DJ. Posterior segment manifestations of active ocular syphilis, their response to a neurosyphilis regimen of penicillin therapy, and the influence of human immunodeficiency virus status on response. Ophthalmology. 2000; 107(11):2015-23. Comment in: Ophthalmology. 2001;108(9):1515-6.

6. Duke-Elder S, Perkins ES. Diseases of the uveal tract. In: Duke-Elder S, editor. System of ophthalmology. St. Louis: Mosby, 1966. vol. 9, p.299-302.

7. Holand GN. Standard diagnostic criteria for the acute retinal necrosis syndrome. Executive Committee of the American Uveitis Society. Am J Ophthalmol. 1994;117(5):663-7.

8. Balansard B, Bodaghi B, Cassoux N, Fardeau C, Romand S, Rozenberg F, et al. Necrotising retinopathies simulating acute retinal necrosis syndrome. $\mathrm{Br} \mathrm{J}$ Ophthalmol. 2005;89(1):96-101.

9. Gass JD, Braunstein RA, Chenoweth RG. Acute syphilitic posterior placoid chorioretinitis. Ophthalmology. 1990;97(10):1288-97.

10. Joseph A, Rogers S, Browning A, Hall N, Barber C, Lotery A, et al. Syphilitic acute posterior placoid chorioretinitis in nonimmuno-compromised patients. Eye (Lond). 2007;21(8):1114-9. 